\title{
Airborne microorganisms in Lascaux Cave (France)
}

\author{
Pedro M. Martin-Sanchez ${ }^{1}$, Valme Jurado ${ }^{1}$, Estefania Porca ${ }^{1}$, Fabiola Bastian², Delphine \\ Lacanette $^{3}$, Claude Alabouvette ${ }^{2}$, and Cesareo Saiz-Jimenez ${ }^{1 *}$ \\ ${ }^{1}$ Instituto de Recursos Naturales y Agrobiología de Sevilla, IRNAS-CSIC, Apartado 1052, 41080 Sevilla, Spain \\ ${ }^{2}$ UMR INRA-Université de Bourgogne, Microbiologie du Sol et de 1’Environnement, BP 86510, 21065 Dijon Cedex, France \\ ${ }^{3}$ Université de Bordeaux, I2M, UMR 5295, 16 Avenue Pey-Berland, 33600 Pessac, France
}

\begin{abstract}
Lascaux Cave in France contains valuable Palaeolithic paintings. The importance of the paintings, one of the finest examples of European rock art paintings, was recognized shortly after their discovery in 1940. In the 60's of the past century the cave received a huge number of visitors and suffered a microbial crisis due to the impact of massive tourism and the previous adaptation works carried out to facilitate visits. In 1963, the cave was closed due to the damage produced by visitors' breath, lighting and algal growth on the paintings. In 2001, an outbreak of the fungus Fusarium solani covered the walls and sediments. Later, black stains, produced by the growth of the fungus Ochroconis lascauxensis, appeared on the walls. In 2006, the extensive black stains constituted the third major microbial crisis. In an attempt to know the dispersion of microorganisms inside the cave, aerobiological and microclimate studies were carried out in two different seasons, when a climate system for preventing condensation of water vapor on the walls was active (September 2010) or inactive (February 2010). The data showed that in September the convection currents created by the climate system evacuated the airborne microorganisms whereas in February they remained in suspension which explained the high concentrations of bacteria and fungi found in the air. This double aerobiological and microclimate study in Lascaux Cave can help to understand the dispersion of microorganisms and to adopt measures for a correct cave management.
\end{abstract}

Keywords: aerobiology; bacteria; fungi; caves; Palaeolithic paintings; culture-dependent methods; climatic simulations

Received 3 December 2013; Revised 10 April 2014; Accepted 24 May 2014

Citation: Martin-Sanchez P.M., Jurado V., Porca E., Bastian F., Lacanette D., Alabouvette C. and Saiz-Jimenez C., 2014. Airborne microorganisms in Lascaux Cave (France). International Journal of Speleology, 43 (3), 295-303. Tampa, FL (USA), ISSN 0392-6672 http://dx.doi.org/10.5038/1827-806X.43.3.6

\section{INTRODUCTION}

Lascaux Cave and other sites in the Vézère Valley, France, were included in the UNESCO World Heritage List in 1979. This cave, discovered in 1940, contains valuable Palaeolithic paintings. The cave was open to the public in 1948 and attracted a large audience which reached 100,000 visitors/year in 1962. This seriously disturbed the cave microclimate and had a strong impact on the ecosystem (Bastian et al., 2010). Unfortunately, at that time, there was no scientific knowledge of cave conservation problems and the huge number of visitors resulted in fatal management errors that marked the future of the cave.

Currently, Lascaux Cave is an endangered cavity that was studied from a microbiological point of view since the 60's of the past century, but unfortunately very few data were published before 2009 (e.g. Lefèvre \& Laporte, 1969; Lefèvre, 1974; Dupont et al.,
2007). In the last 50 years the cave suffered several microbiological crises (outbreak of microorganisms threatening the paintings) due to the invasion of the alga Bracteacoccus minor in 1963 (Lefèvre, 1974) and the fungus Fusarium solani in 2001 (Dupont et al., 2007). At present, the paintings are threatened by black stains produced by the fungus Ochroconis lascauxensis (Martin-Sanchez et al., 2012a) as documented in the pictures published by Bastian et al. (2010) and Jurado Lobo et al. (2010).

In the last few years several reports on the microbiology of this cave were published, which contributed to understand the complex processes of microbial colonization and biodeterioration of the cave and its paintings (Bastian et al., 2009, 2010; MartinSanchez et al., 2012 a,b; Saiz-Jimenez et al., 2012).

One of the aspects more neglected in cave research is the study of cave aerobiology, although this issue is of great interest for a correct cave management. 
A historical overview revealed that until the 1970's, a monitoring of the microbiological contamination of Lascaux Cave was carried out by the Institute Pasteur (Paris, France). According to our knowledge, data about the aerobiological studies performed on those dates were no published. The task of the sanitary monitoring, including the evaluation of airborne bacteria, fungi and algae was then passed to the Laboratoire de Recherche des Monuments Historiques (LRMH, Champs-sur-Marne, France). For twenty years (from 1970 to 1990), a passive method based on the gravity effect was used to collect airborne microorganisms by LRMH. Open Petri dishes were exposed on the floor for five minutes for bacteria and fungi, or 24 hours for algae. About ten sampling points located inside the cave and in the entrance airlock chamber were checked using this protocol twice a year (Orial et al., 2011). The resulting counts using the passive method varied within very low ranges, from 0 to 15 colony-forming units (cfu) per plate for both bacteria and fungi. The sampling method was changed in 1990 to an active method, based on the suction and pumping of air samples onto culture media. The results published by Orial et al. (2011) were focused on total quantifications of cultivable bacteria and fungi corresponding to the active monitoring carried out until 2009. In summary, they remarked different periods in Lascaux Cave. From 1990 to 2000, the counts remained within low ranges $\left(0-150 \mathrm{cfu} / \mathrm{m}^{3}\right.$ for bacteria and $0-50 \mathrm{cfu} / \mathrm{m}^{3}$ for fungi). In December 2001, when the Fusarium solani outbreak started, the fungal quantifications reached in general low-medium levels $\left(50-250 \mathrm{cfu} / \mathrm{m}^{3}\right)$. From 2002 to 2003, the bacterial and fungal counts varied between very low and medium ranges $\left(0-250 \mathrm{cfu} / \mathrm{m}^{3}\right)$. In 2004, the levels of bacteria and fungi were particularly increased reaching a high level $\left(250-500 \mathrm{cfu} / \mathrm{m}^{3}\right)$ in December, and even surpassing it in some halls. This increase was directly related to the frequent human activities performed in those dates. Since then, from 2006 to 2009, the microbial contamination fell notably and returned to lower levels. Very little information was provided on the identification of microorganisms detected in this study, only the most abundant genera: Fusarium, Cladosporium, Gliomastix, Penicillium and Aspergillus for fungi, and Bacillus, Staphylococcus and Micrococcaceae family for bacteria (Orial et al., 2011).

Few works about aerobiology of caves have been published using different collection methods, mainly passive samplings (Monte \& Ferrari, 2000; Nugari \& Roccardi, 2001), a Hirst-type volumetric spore trap (Docampo et al., 2011), or a six-stage Anderson FA-1 sampler (Wang et al., 2010). Recently, Porca et al. (2011) used a Duo SAS Super 360 air sampler for evaluating the cultivable fungal communities of caves and proposed a biological index of fungal contamination.

Nowadays, in Lascaux Cave, there is a climatecontrol system located in the machine room, below airlock 1 (Fig. 1a), which generates a cold point where the condensation of water vapor is forced preventing this phenomenon on the walls of the cave during the warm months (from March to September, generally).
The system is also dedicated to recreate convection currents during these months. When the air located in the deeper parts of the cave is colder than the upper parts air, convection currents disappear. The artificial creation of a cold point in an area close to the upper parts (the machine room) helps the formation of convection currents. When the convection currents are present, airborne microorganism dispersion is higher than the case of stratified air. When there is no convection, microorganisms are staying in suspension, and are no more evacuated.

The objectives of the present study were to report on airborne bacteria and fungi in Lascaux Cave as well as to know their dispersion mechanisms inside the cave, data which allow integrating the knowledge acquired in the last years on the cave microbial ecology. To reach it, aerobiological and microclimate studies were carried out in two different seasons, when a climate system for preventing condensation of water vapor on the walls was active (September 2010) or inactive (February 2010). The microbial communities were characterized by isolation and molecular identification of cultivable strains from air samples collected by Duo SAS Super 360. It was expected that these data would contribute to the conservation of this fragile cave.

\section{MATERIAL AND METHODS}

\section{Sampling}

Lascaux Cave is located in the basin of Vézère River, near the town of Montignac, in the Black Perigord area, Dordogne, France (453'13.3'N, 1'10'12"E). The total length of the known subterranean system is less than $250 \mathrm{~m}$, with an accessible volume of $3,300 \pm 500 \mathrm{~m}^{3}$, as shown in Fig. 1a. The galleries of Lascaux Cave are situated at shallow depth, between 10 and $25 \mathrm{~m}$ below the current ground level, in the heterothermal zone of the soil. The average air temperature, which is relatively constant all year round, is $12.5^{\circ} \mathrm{C}$, and the average relative humidity is 99\% (Malaurent et al., 2011).

Two surveys were conducted in Lascaux Cave at different dates, on 16th February and 21st September in 2010, in which were collected air samples from the same nine points shown in Fig. 1a. Eight of them were located at different halls within the cave (A2A9), and one additional sampling point was located outside the cave as control (A1).

A Duo SAS Super 360 air sampler (VWR-pbi, Milan, Italy), shown in Fig. 1b, was used to detect cultivable microorganisms in both surveys. Two replicates of air samples (100 L each one) were directly aspirated, using a 219-hole impactor, onto the appropriate culture media contained in $90 \mathrm{~mm}$ Petri dishes. The culture plates were kept at room temperature until arrival in the laboratory, where they were directly processed as detailed below. The appropriate volumes of air samples were based on a previous study (Porca et al., 2011). Volumes higher than $100 \mathrm{~L}$, collected by Duo SAS sampler, resulted in an excessive number of colonies grown on the culture medium to be efficiently counted. 


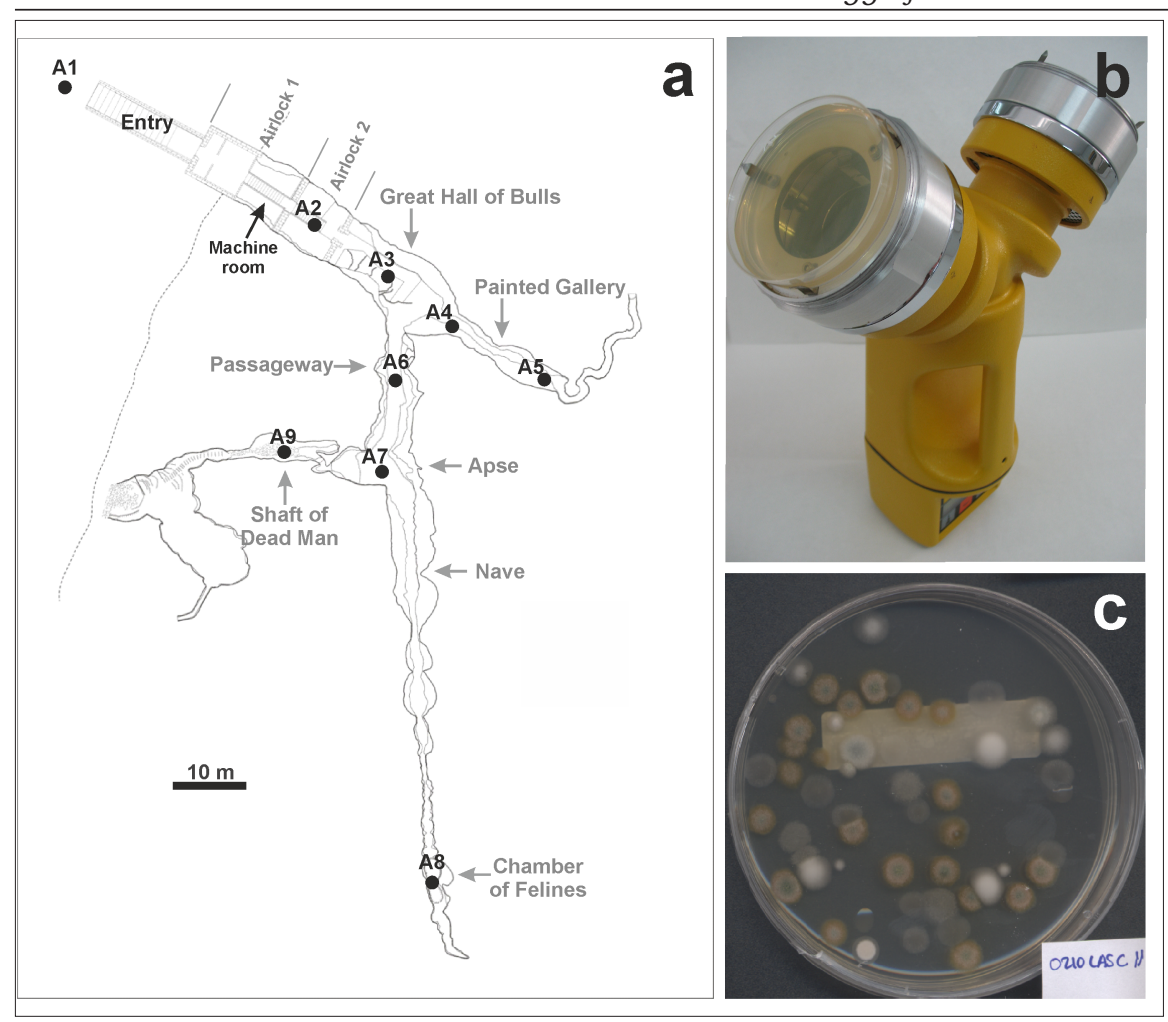

Fig. 1. a) Map of Lascaux Cave with locations of air samples collected in this study; b) DUO SAS Super 360 air sampler used to detect cultivable microorganisms; c) Fungal colonies grown on MEA medium at $24^{\circ} \mathrm{C}$ for seven days.

\section{Isolation and counting of airborne microorganisms}

Bacteria were isolated on trypticase soy agar medium (TSA) with $50 \mathrm{mg} / \mathrm{L}$ cycloheximide to inhibit the eukaryotic organisms, and fungi were isolated on malt extract agar medium (MEA) including $50 \mathrm{mg} / \mathrm{L}$ chloramphenicol which inhibits a wide variety of bacteria. The plates were incubated at $24^{\circ} \mathrm{C}$ for five or seven days, for bacteria and fungi respectively. Although the microorganisms dwelling Lascaux Cave must be adapted to oligotrophic conditions and temperatures around $12^{\circ} \mathrm{C}$ (average temperature in the cave), we used nutrient culture media incubated at higher temperature in order to accelerate microbial growth and to allow isolations and representative counts in a fixed incubation period. Viable counts and isolations in pure culture were independently performed for each colony type with different morphological characters (Fig. 1c), and for each replicate of air sample. The final amounts of bacteria and fungi in each air sample were expressed as colonyforming units per cubic meter following the Duo SAS sampler manufacturer's instructions. The number of colonies counted on the surface of the culture plates was corrected for the statistical possibility of multiples particles passing through the same hole. Bacterial strains were stored in $20 \%$ glycerol at $-80^{\circ} \mathrm{C}$. Fungal strains were previously grown on MEA slants and subsequently stored at $4^{\circ} \mathrm{C}$.

\section{Molecular identification}

Identification of strains was based on the molecular analysis of ribosomal DNA sequences. Genomic DNA from strains was extracted by collecting bacterial or fungal biomass from pure cultures and transferring it to a $1.5 \mathrm{ml}$ Eppendorf tube containing $500 \mu \mathrm{L}$ TNE buffer (10 mM Tris-HCl, $100 \mathrm{mM}$ $\mathrm{NaCl}, 1 \mathrm{mM}$ EDTA; $\mathrm{pH}$ 8) and glass beads. The mixture was shaken in a cell disrupter Fast Prep-24 (MP Biomedicals, Solon, OH, USA) at full speed for $3 \mathrm{~min}$. The DNA was purified by phenol/chloroform extraction and ethanol precipitation.

The bacterial 16S rDNA was amplified by PCR using the primers 616F 5'-AGAGTTTGATYMTGGCTCAG-3' (Snaidr et al., 1997) and 1510R 5'-GGTTACCTTGTTACGACTT-3' (Lane 1991). The fungal internal transcribed spacer (ITS) regions, including ITS1, 5.8S rDNA and ITS2, were amplified using the primers ITS1 5'-TCCGTAGGTGAACCTGCGG-3' and ITS45'-TCCTCCGCTTATTGATATGC-3' (White et al., 1990). PCR reactions were performed in $50 \mu \mathrm{L}$ volumes, containing $5 \mu \mathrm{L}$ of $10 \mathrm{x}$ PCR buffer, $2 \mu \mathrm{L}$ of $50 \mathrm{mM} \mathrm{MgCl} 2,5 \mu \mathrm{L}$ of $2 \mathrm{mM}$ dNTP mix (Invitrogen, Carlsbad, CA, USA), $0.5 \mu \mathrm{L}$ of $50 \mu \mathrm{M}$ of each primer (Macrogen, Seoul, Korea), 10-20 ng of the extracted DNA as template, 1.25 units of Taq DNA polymerase (Bioline, GC Biotech, The Netherlands), and the rest of volume of sterile ultrapure water. Reactions were performed in duplicate, and negative controls (containing no DNA) were included in each PCR trial. PCR amplifications were performed in a BioRad iCycler thermal cycler (BioRad, Hercules, CA, USA) using the following cycling parameters: 2 min of initial denaturing step at $95^{\circ} \mathrm{C}$, followed by 35 cycles of denaturing $\left(95^{\circ} \mathrm{C}\right.$ for $1 \mathrm{~min})$, annealing $\left(55^{\circ} \mathrm{C}\right.$ for $\left.1 \mathrm{~min}\right)$ and extension $\left(72^{\circ} \mathrm{C}\right.$ for $2 \mathrm{~min}$ ), with an additional extension step at $72^{\circ} \mathrm{C}$ for $10 \mathrm{~min}$ at the end. To evaluate the PCR results, all products were electrophoresed on $1 \%(\mathrm{w} / \mathrm{v})$ agarose gels, stained with SYBR Green I (Roche Diagnostics, Mannheim, Germany) and visualized under UV light.

Positive PCR products were sent to Macrogen Inc. (Amsterdam, The Netherlands) for purification and sequencing using the same primer set. In order to approximate the phylogenetic identification of strains, the received sequences were compared, using BLASTn algorithm, to the non-redundant databases of sequences deposited at the National Center for Biotechnology Information (NCBI). Additionally, the EZtaxon web-based tool was also used for bacteria identification.

\section{Climatic numerical simulations}

In 2010, the climate-control system was running during the second survey in September but not in February. More precisely, it was switched on June 22nd and switched off November 16th. Numerical simulations of thermal configurations in both sampling dates were performed with Thétis (www.thetis.enscbp. fr), a CFD (Computational Fluid Dynamics) code developed by a team from the Institute of Mechanics and Engineering at the University of Bordeaux, 
France. It is a research code for modeling and numerical simulation of fluid mechanics problems. The code has been adapted to underground areas and more specifically rock art caves (Lacanette et al., 2009). It is dedicated to study the links between the distribution of temperature, the air velocities and the rate of humidity, as these parameters largely impact on the conservation of these sites. The simulations constitute a way for helping to make the decisions regarding their conservation.

\section{RESULTS AND DISCUSSION}

In this study, analysis of air samples, collected with a Duo SAS sampler, allowed achieving a representative inventory of the cultivable bacteria and fungi present in the Lascaux Cave. Of course, whenever a dependent-culture approach is used it must be assumed some lack of diversity due to the selected culture conditions. We used nutrient culture media incubated at $24^{\circ} \mathrm{C}$ in aerobic conditions for a restricted period of time; such conditions have favored certain microorganisms against another. However, the selected methods resulted useful recovering a significant microbial diversity and estimating their abundance and evolution in two different seasons.

Quantifications of cultivable bacteria were higher than fungi in all sampled areas in the two surveys (Table 1). Amounts of bacteria and fungi inside the cave (samples A2-A9) were much higher in February than in September. In contrast, the counts obtained outside the cave (A1) generally showed an opposite trend. They were lower than inside the cave in February and higher in September (Table 1). In both samplings, the lowest amounts of bacteria and fungi were quantified in the Shaft of Dead Man (A9) which is the most inaccessible hall, and rarely visited for scientific and conservation works.

Numerical simulation of the two thermal configurations was also accomplished. In February (Fig. 2) air velocity is lower than in September (Fig. 3). The air temperature in February is higher than in September. Lascaux is a shallow cave, it is located at $10 \mathrm{~m}$ depth, and the temperature wave requires 6 months to reach the cave, which explains why the

Table 1. Viable counts of microorganisms in air samples collected from Lascaux Cave

\begin{tabular}{|l|l|l|l|l|}
\hline \multirow{2}{*}{ Sampling point: Hall } & \multicolumn{2}{|c|}{ Bacteria $\left(\mathrm{cfu} / \mathrm{m}^{3}\right)^{\star}$} & \multicolumn{2}{c|}{ Fungi $\left(\mathrm{cfu} / \mathrm{m}^{3}\right)^{\star}$} \\
\cline { 2 - 5 } & February & September & February & September \\
\hline A1: Outdoor & $360 \pm 78$ & $1,090 \pm 71$ & $170 \pm 14$ & $960 \pm 42$ \\
\hline A2: Airlock 2 & $4,550 \pm 311$ & $700 \pm 233$ & $460 \pm 267$ & $170 \pm 21$ \\
\hline A3: Great Hall of Bulls & $2,490 \pm 78$ & $980 \pm 63$ & $200 \pm 35$ & $140 \pm 42$ \\
\hline $\begin{array}{l}\text { A4: Painted Gallery } \\
\text { (entrance area) }\end{array}$ & $4,470 \pm 56$ & $420 \pm 226$ & $290 \pm 177$ & $170 \pm 42$ \\
\hline $\begin{array}{l}\text { A5: Painted Gallery } \\
\text { (deep area) }\end{array}$ & $4,050 \pm 792$ & $360 \pm 283$ & $950 \pm 7$ & $190 \pm 42$ \\
\hline A6: Passageway & $1,120 \pm 219$ & $540 \pm 21$ & $150 \pm 7$ & $80 \pm 28$ \\
\hline A7: Apse (lower area) & $1,500 \pm 853$ & $760 \pm 163$ & $690 \pm 71$ & $120 \pm 35$ \\
\hline A8: Chamber of Felines & $15,520 \pm 49$ & $740 \pm 226$ & $700 \pm 551$ & $190 \pm 56$ \\
\hline A9: Shaft of Dead Man & $310 \pm 127$ & $70 \pm 56$ & $50 \pm 42$ & $10 \pm 7$ \\
\hline *Valu are ava & & & & \\
\hline
\end{tabular}

* Values are averages of two replicates with standard errors, expressed as colony forming units per cubic meter of sampled air. These data were previously corrected following the manufacturer's instructions.

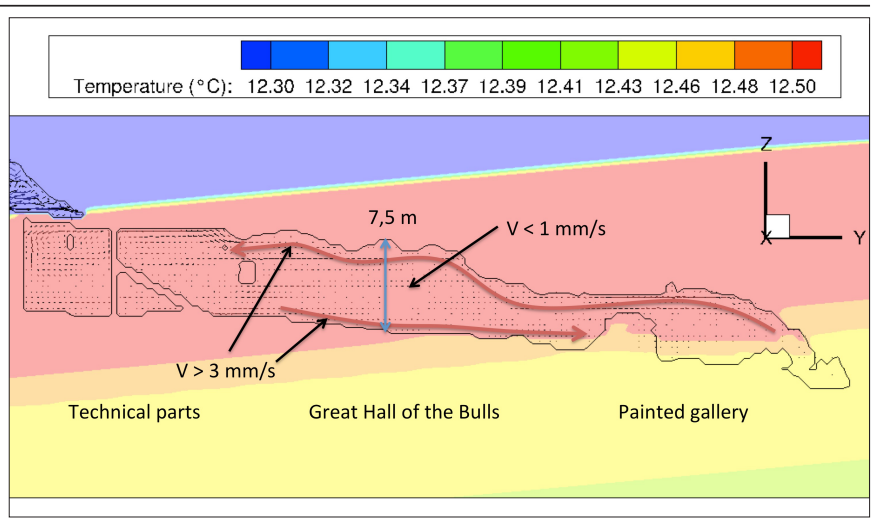

Fig. 2. Numerical simulation of the thermal configuration of 16th February 2010 on a slice of the Lascaux Cave, colors are for temperature, vectors are for the air velocity.

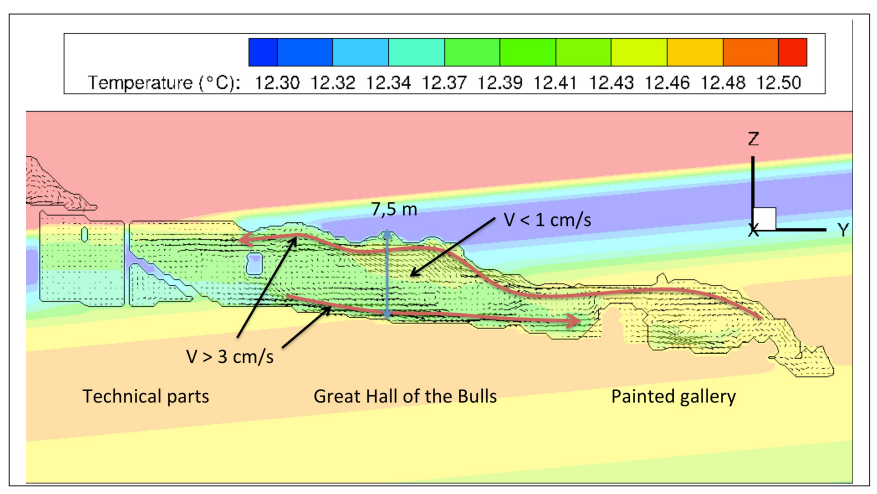

Fig. 3. Numerical simulation of the thermal configuration of 21st September 2010 on a slice of the Lascaux Cave, colors are for temperature, vectors are for the air velocity.

higher temperatures in the cave are in winter and the lower in summer.

Considering the Great Hall of the Bulls, in February the temperature difference between the ground and the vaults was $0.3^{\circ} \mathrm{C}$ for a height of $7.5 \mathrm{~m}$. The air at a higher temperature was located on the vaults, as it is lighter than the colder one and stays in this area. Therefore the air was stratified, with an air velocity of $1 \mathrm{~mm} / \mathrm{s}$ in the center of the hall and $3 \mathrm{~mm} / \mathrm{s}$ at the boundaries. In the same place in September, the machine system involved the presence of a cold point in the machine room, which created convection currents in the Great Hall of the Bulls. Convection currents homogenized the air; the temperature difference was only $0.05^{\circ} \mathrm{C}$ but the velocity at the center of the hall was about $1 \mathrm{~cm} / \mathrm{s}$ and $3 \mathrm{~cm} / \mathrm{s}$ at the boundaries, i. e. 10 times bigger than in February.

In September the convection created by the machine system evacuated the airborne microorganisms, whereas in February, they remained in suspension in the air.

\section{Airborne bacteria}

The bacterial phylotypes detected from air samples of Lascaux Cave differed significantly in each season (Table 2). Globally, the majority of bacterial phylotypes corresponded to the phylum Actinobacteria $(44.1 \%$ of total phylotypes), followed by Proteobacteria (26.5\%), Firmicutes (23.5\%) and Bacteroidetes (5.8\%).

High levels of bacteria were generally quantified inside the cave in February (A2-A8) (Table 1). They were much higher (from 2 to 30 times) than the "very 
Table 2. Bacteria retrieved from air samples collected from Lascaux Cave.

\begin{tabular}{|c|c|c|c|c|c|c|c|c|c|c|c|c|c|c|c|c|c|c|c|}
\hline \multirow{2}{*}{$\begin{array}{l}\text { Representative strains of } \\
\text { phylotypes }^{\mathrm{a}} \\
\text { (Accession Number) }^{\text {A }}\end{array}$} & \multirow{2}{*}{$\begin{array}{l}\text { Molecular identification } \\
\text { (Similarity \%) }\end{array}$} & \multicolumn{9}{|c|}{ Abundance $^{c}$ - February 2010} & \multicolumn{9}{|c|}{ Abundance $^{C}$ - September 2010} \\
\hline & & $\mathrm{A} 1$ & $\mathrm{~A} 2$ & $\mathrm{~A} 3$ & A4 & A5 & A6 & A7 & A8 & A9 & A1 & $\mathrm{A} 2$ & $\mathrm{~A} 3$ & A4 & A5 & A6 & A7 & A8 & A9 \\
\hline \multicolumn{20}{|l|}{ Actinobacteria } \\
\hline B0210-14M4 (HG008781) & Agrococcus jenensis (99) & ++ & - & - & - & - & ++ & + & + & ++ & - & - & + & - & - & - & - & - & - \\
\hline B0910-22U3 (HG008782) & Agromyces fucosus (99) & - & - & - & - & - & - & - & - & - & - & - & - & - & - & ++ & - & - & - \\
\hline B0210-54A3 (HG008783) & Arthrobacter arilaitensis (99) & + & - & - & - & - & - & - & - & - & - & - & - & - & - & - & - & - & - \\
\hline B0210-54A4 (HG008784) & Arthrobacter sulfonivorans (99) & + & - & - & - & - & - & - & - & - & - & - & - & - & - & - & - & - & - \\
\hline B0210-C10 (HG008785) & Brachybacterium fresconis (99) & ++ & +++ & +++ & +++ & +++ & ++ & +++ & +++ & - & - & - & - & - & - & - & - & - & - \\
\hline B0910-55A6 (HG008786) & $\begin{array}{l}\text { Curtobacterium flaccumfaciens } \\
\text { (99) }\end{array}$ & - & - & - & - & - & - & - & - & - & + & - & - & - & - & - & - & - & - \\
\hline B0210-56B3 (HG008787) & Curtobacterium herbarum (99) & + & + & - & - & - & - & - & - & - & - & - & - & - & - & - & - & - & - \\
\hline B0210-914 (HG008788) & Janibacter limosus (99) & - & - & - & - & - & - & - & - & + & - & - & - & + & - & - & - & - & - \\
\hline B0910-13LL2 (HG008789) & Microbacterium murale (99) & - & - & - & - & - & - & - & - & - & - & + & ++ & +++ & - & - & +++ & ++ & - \\
\hline B0210-22U5 (HG008790) & Microbacterium oxydans (98) & ++ & - & ++ & + & - & ++ & - & - & - & - & - & - & - & - & - & - & - & - \\
\hline B0210-32E2 (HG008791) & Micrococcus yunnanensis (99) & - & - & - & + & - & - & - & + & - & - & - & - & - & - & - & - & - & - \\
\hline B0910-42N2 (HG008792) & Rhodococcus erythropolis (99) & - & - & - & - & - & - & - & - & - & - & +++ & + & + & - & - & - & + & ++ \\
\hline B0210-56B2 (HG008793) & Rhodococcus globerulus (99) & ++ & - & - & + & - & - & - & + & + & - & - & - & - & - & - & - & - & - \\
\hline B0210-50V9 (HG008794) & Streptomyces subrutilus (100) & - & + & - & + & + & + & + & + & ++ & - & + & - & - & - & - & + & + & - \\
\hline B0210-28A5 (HG008795) & Zhihengliuella aestuarii (99) & - & + & ++ & + & + & - & - & - & - & - & - & - & - & - & - & ++ & ++ & - \\
\hline \multicolumn{20}{|l|}{ Bacteroidetes } \\
\hline B0210-50V2 (HG008796) & Flavobacterium chilense (99) & - & + & - & - & - & - & - & - & - & - & - & - & - & - & - & - & - & - \\
\hline B0210-32E4 (HG008797) & $\begin{array}{l}\text { Pseudosphingobacterium } \\
\text { domesticum (99) }\end{array}$ & - & + & + & + & + & + & - & - & + & - & - & + & - & - & - & - & - & ++ \\
\hline \multicolumn{20}{|l|}{ Firmicutes } \\
\hline B0210-56B5 (HG008798) & Bacillus licheniformis (99) & + & - & - & - & - & - & - & - & - & - & - & - & - & - & - & - & - & - \\
\hline B0210-8H1 (HG008799) & Bacillus muralis (99) & - & - & - & + & - & - & - & - & + & - & - & - & - & - & - & - & - & ++ \\
\hline B0210-14M1 (HG008800) & Bacillus mycoides (99) & + & + & - & - & + & + & + & - & + & - & - & - & ++ & +++ & +++ & + & - & ++ \\
\hline B0210-13LL2 (HG008801) & Bacillus pulmilus (99) & - & - & - & - & - & - & ++ & - & - & - & - & - & - & - & - & - & - & - \\
\hline B0910-4D1 (HG008802) & Bacillus simplex (99) & - & - & - & - & - & - & - & - & - & - & - & - & - & - & - & - & ++ & - \\
\hline B0910-57A7 (HG008803) & $\begin{array}{l}\text { Bacillus weihenstephanensis } \\
(100)\end{array}$ & - & - & - & - & - & - & - & - & - & ++ & - & - & - & - & - & - & - & - \\
\hline B0210-55A1 (HG008804) & Staphylococcus equorum (99) & + & - & - & - & - & - & - & - & - & - & - & - & - & - & - & - & - & - \\
\hline B0910-56B1 (HG008805) & Staphylococcus lentus (99) & - & - & - & - & - & - & - & - & - & + & - & - & - & - & - & - & - & - \\
\hline \multicolumn{20}{|l|}{ Alphaproteobacteria } \\
\hline B0910-28A1 (HG008806) & $\begin{array}{l}\text { Phyllobacterium ifriqiyense } \\
\text { (99) }\end{array}$ & - & - & - & - & - & - & - & - & - & - & - & + & - & + & - & - & - & - \\
\hline B0210-22U3 (HG008807) & Sphingomonas faeni (98) & - & - & - & - & - & + & - & - & - & - & - & - & - & - & - & - & - & - \\
\hline \multicolumn{20}{|l|}{ Betaproteobacteria } \\
\hline B0210-50V6 (HG008808) & Advenella kashmirensis (99) & - & + & - & - & - & - & - & - & - & - & - & - & - & - & - & - & - & - \\
\hline B0210-28A7 (HG008809) & Massilia timonae (99) & - & - & - & - & + & - & - & + & - & - & - & - & - & - & - & - & - & - \\
\hline \multicolumn{20}{|l|}{ Gammaproteobacteria } \\
\hline B0910-23V4 (HG008810) & Acinetobacter johnsonii (99) & - & - & - & - & - & - & - & - & - & - & - & - & - & - & + & - & - & - \\
\hline B0210-3C7 (HG008811) & Acinetobacter /woffii (99) & - & + & - & - & + & - & - & + & - & - & - & - & - & - & - & - & - & - \\
\hline B0210-45N5 (HG008812) & Pseudomonas stutzeri (99) & - & + & + & - & + & + & - & - & ++ & +++ & + & + & + & ++ & + & + & - & - \\
\hline B0910-8H1 (HG008813) & $\begin{array}{l}\text { Pseudomonas xanthomarima } \\
\text { (99) }\end{array}$ & - & - & - & - & - & - & - & - & - & - & - & - & - & - & - & - & - & ++ \\
\hline B0910-56B4 (HG008814) & $\begin{array}{l}\text { Stenotrophomonas maltophilia } \\
\text { (99) }\end{array}$ & - & - & - & - & - & - & - & - & - & + & - & - & - & - & - & - & - & - \\
\hline
\end{tabular}

high" contamination level $\left(>500 \mathrm{cfu} / \mathrm{m}^{3}\right)$ previously described by Orial et al. (2011) in Lascaux. The maximum amount of bacteria was achieved in the Chamber of Felines (A8; $\left.1.5 \times 10^{4} \mathrm{cfu} / \mathrm{m}^{3}\right)$, followed by the counts obtained along the main axis of the cave, from Airlock 2 to deep Painted Gallery (A2-A5; counts ranged from 2.4 to $4.5 \times 10^{3} \mathrm{cfu} / \mathrm{m}^{3}$ ).

The most abundant species in February was Brachybacterium fresconis, detected both outside and inside the cave, in all halls except the Shaft of the Dead Man (A9). However, this actinobacterium was not detected in September (Table 2). This species was previously described on mural painting of the Saint-Catherine chapel at Castle Herberstein, Austria (Heyrman et al., 2002). Other abundant bacterium was Microbacterium murale present in the Great Hall of Bulls, Painted Gallery, Apse and Chamber of Felines, but only in the September sampling. This bacterium was recently isolated and described from a cellar wall (Kämpfer et al., 2012).

Species of the genus Bacillus, belonging to the Firmicutes phylum, were frequently isolated in all areas 
of Lascaux Cave, except the Great Hall of Bulls (Table 2). Bacillus strains have been previously isolated from Lascaux Cave (Orial et al., 2011), Altamira Cave in Spain (Laiz et al., 1999), Grotta dei Cervi in Italy (Laiz et al., 2000a), and Sahastradhara, Mawsmai and Krem Phyllut caves in India (Baskar et al., 2006, 2009). The most abundant Bacillus species was B. mycoides, detected in six air samples in February and five in September. Strains of $B$. mycoides, capable to precipitate calcite in vitro, were isolated from wall deposit in Krem Phyllut Cave, India (Baskar et al., 2009).

The most abundant Proteobacteria, with five positive samples in February and seven in September, was identified as Pseudomonas stutzeri. This Pseudomonas species is usually found in caves and catacombs subjected to strong anthropogenic impact (Laiz et al., 2000b; De Leo et al., 2012), and in contaminated environments (Mulet et al., 2011). Like other Pseudomonas species, $P$. stutzeri is involved in environmentally important metabolic activities related to metal cycling and degradation of biogenic and xenobiotic compounds (oil derivatives, aromatic and non-aromatic hydrocarbons and biocides) (Lalucat et al., 2006).

In September, the bacterial contamination levels were considerably reduced inside the cave (Table 1). However, the counts in A2-A8 would belong to the "high" (250-500 cfu/m³) or "very high" (> $500 \mathrm{cfu} / \mathrm{m}^{3}$ ) levels defined by Orial et al. (2011).

\section{Airborne fungi}

Similar to bacterial communities, the fungal phylotypes in each season varied significantly (Table 3). Overall, the majority of fungal phylotypes corresponded to the phylum Ascomycota (80.8\% of total phylotypes), and the rest to Basidiomycota (19.2\%).

In February, the fungal contamination levels inside the cave were quite high, generally ranging from 150 - $950 \mathrm{cfu} / \mathrm{m}^{3}$ (Table 1). The maximum amount of fungi was achieved in the deep Painted Gallery (A5; $950 \mathrm{cfu} / \mathrm{m}^{3}$ ) followed by the Chamber of Felines (A8; $\left.700 \mathrm{cfu} / \mathrm{m}^{3}\right)$. According to Porca et al. (2011), these levels would be within the categories 3 or 4, which corresponded to a cave already affected by fungi.

The most abundant species in February were Aspergillus versicolor and Verticillium leptobactrum, which were isolated from five sampling points located inside the cave (Table 3 ). High concentrations of $A$. versicolor were reached in the Chamber of Felines (87.6\% of total colonies) and in the Apse (40.1\%). This species was previously found in Lascaux Cave (Bastian et al., 2009), and other caves from India (Koilraj et al., 1999), Slovakia (Nováková, 2009) and Spain (Dominguez-Moñino et al., 2012). High concentrations of $V$. leptobactrum were found in February in the Shaft of the Dead Man (76\%) and in the entrance of the Painted Gallery (40.1\%), and in September in the Apse (26.6\%). Bastian et al. (2009) also detected V. leptobactrum in the clone libraries constructed with wall and sediment samples from this cave. This fungal species is a well know parasite of nematodes (Godoy et al., 1982), hence, its abundance may indicate a relevant population of nematodes in Lascaux Cave, which presence was already reported by Lefèvre (1974).
Species of the genera Cladosporium and Penicillium were frequently isolated in February and September from both outside and inside the cave (Table 3); they are saprophytic fungi with cosmopolitan distribution. Both genera were previously detected in the air of Lascaux Cave (Orial et al., 2011). Aspergillus/ Penicillium was the most abundant spore type found in the air of Nerja Cave, which represented $50 \%$ of the total spores, followed by Cladosporium with $17 \%$ (Docampo et al., 2011). Strains of Cladosporium and Penicillium were frequently isolated from air samples in other Spanish caves (Domínguez-Moñino et al., 2012), and from various cave samples in the Domica Cave, Slovakia (Nováková, 2009).

Some others fungi, widely distributed in Lascaux Cave, were identified as Doratomyces sp., Geomyces pannorum, Gliomastix murorum, and Ochroconis lascauxensis (Table 3). Doratomyces spp. were also isolated from caves in Slovakia (Nováková, 2009), Japan (Nagai et al. 1998) and USA (Vaughan et al., 2011). Geomyces pannorum was previously reported in Lascaux Cave (Bastian et al., 2009) and Domica Cave (Nováková, 2009). Members of the Gliomastix genus were isolated from air in Lascaux Cave (Orial et al., 2011). Ochroconis lascauxensis was recently described as the fungus responsible of the black stains outbreak in Lascaux Cave (Martin-Sanchez et al., 2012a).

In September, the fungal contamination levels were considerably reduced inside the cave, ranging from 10 - $190 \mathrm{cfu} / \mathrm{m}^{3}$ (Table 1). The maximum amount of fungi was achieved in both the deep Painted Gallery and the Chamber of Felines (A5 and A8; $190 \mathrm{cfu} / \mathrm{m}^{3}$ ). These concentrations would be mainly within the category 2 defined by Porca et al. (2011), or between the "very low" and "medium" levels defined by Orial et al. (2011).

In contrast with the fungal variability detected in February, all grown colonies from the Passageway (A6) in September were identified as Bulleromyces albus (Table 3). The yeast $B$. albus produces ballistospores which are discharged to the air with a high acceleration. This species also secretes a killer toxin inhibitory to many ascomycetous and basidiomycetous yeast-like fungi (Golubev et al., 1997). According to these data, probably, B. albus ballistospores were being discharged near to the Duo SAS sampler during the collection of A4 and A6 samples in September. Thus, its high concentration likely interfered in the isolation of other fungi.

Regarding Ochroconis lascauxensis, this species was isolated in February from five halls inside the cave, with percentages of colonies ranging from 1.6 to $24 \%$, reaching the maximum in the Chamber of Felines. In September, no colony of this fungus was detected in any sample (Table 3). However, in a previous study using a specific and very sensitivity real-time PCR method, O. lascauxensis was detected in air samples collected at the same date (21 September 2010) from five halls of Lascaux Cave using a Coriolis sampler which permitted the detection of fungal DNA collected in a liquid support (Martin-Sanchez et al., 2013). The concentrations of $O$. lascauxensis DNA detected by real-time PCR ranged from 8.8 to $35.3 \mathrm{pg} / \mathrm{m}^{3}$, reaching the maximum in the Passageway. These low 
Table 3. Fungi retrieved from air samples collected from Lascaux Cave.

\begin{tabular}{|c|c|c|c|c|c|c|c|c|c|c|c|c|c|c|c|c|c|c|c|}
\hline \multirow{2}{*}{$\begin{array}{l}\text { Representative strains of } \\
\text { phylotypes }^{\mathrm{a}} \\
\text { (Accession Number) }^{\text {(a) }}\end{array}$} & \multirow{2}{*}{$\begin{array}{l}\text { Molecular identification } \\
\text { (Similarity \%) }\end{array}$} & \multicolumn{9}{|c|}{ Abundance $^{c}$ - February 2010} & \multicolumn{9}{|c|}{ Abundance $^{\mathrm{C}}$ - September 2010} \\
\hline & & A1 & A2 & A3 & A4 & A5 & A6 & A7 & A8 & A9 & A1 & A2 & A3 & A4 & A5 & A6 & A7 & A8 & A9 \\
\hline \multicolumn{20}{|l|}{ Ascomycota } \\
\hline F0210-11K1 (HG008742) & Acremonium nepalense (99) & - & - & - & - & - & + & + & - & - & - & - & - & - & - & - & - & - & - \\
\hline F0210-12L1 (HG008743) & Alternaria sp. (100) & - & - & - & - & - & - & + & - & - & + & - & - & - & - & - & - & - & - \\
\hline F0210-31D2 (HG008744) & Aspergillus cavernicola (99) & - & - & - & + & - & - & - & - & - & - & - & - & - & - & - & - & - & - \\
\hline F0210-1A3 (HG008745) & Aspergillus versicolor (99) & - & + & ++ & - & ++ & - & ++ & +++ & - & - & - & - & - & - & - & - & - & - \\
\hline F0910-49U4 (HG008746) & Cladosporium sp. (100) & ++ & - & - & +++ & - & - & - & + & - & ++ & ++ & - & +++ & + & - & + & ++ & +++ \\
\hline F0210-39L3 (HG008747) & Coniothyrium sp. (99) & - & - & + & - & - & - & - & - & - & - & - & - & - & - & - & - & - & - \\
\hline F0210-40L4 (HG008748) & Debaryomyces sp. (99) & - & - & + & - & - & - & - & - & - & - & - & - & - & - & - & - & - & - \\
\hline F0910-7G1 (HG008749) & Doratomyces sp. (98) & - & - & - & + & ++ & + & + & - & - & - & - & +++ & - & - & - & - & ++ & - \\
\hline F0910-53Y1 (HG008750) & Epicoccum nigrum (99) & - & - & - & - & - & - & - & - & - & ++ & - & - & - & - & - & - & - & - \\
\hline F0210-20S4 (HG008751) & Geomyces pannorum (100) & - & + & + & + & - & + & - & - & - & - & - & - & - & - & - & - & - & - \\
\hline F0210-2B2 (HG008752) & Gliomastix murorum (100) & - & +++ & - & - & ++ & - & - & + & - & - & - & - & - & - & - & - & - & - \\
\hline F0910-48T4 (HG008753) & Hirsutella sp. (98) & - & - & - & - & - & - & - & - & - & - & ++ & - & - & - & - & - & - & - \\
\hline F0210-49U4 (HG008754) & Hormonema dematioides (99) & - & + & - & - & - & - & - & - & - & + & - & - & - & - & - & - & - & - \\
\hline F0210-21T1 (HG008755) & Hypocreales sp. (99) & - & - & ++ & - & - & ++ & - & - & - & - & - & - & - & - & - & - & - & - \\
\hline F0210-20S2 (HG008756) & Mortierella sp. (99) & - & - & ++ & - & - & ++ & - & - & - & - & - & - & - & - & - & - & ++ & - \\
\hline F0210-7G2 (HG008757) & Ochroconis lascauxensis (100) & - & - & + & - & + & + & + & - & ++ & - & - & - & - & - & - & - & - & - \\
\hline F0210-26Y1 (HG008758) & Penicillium sp. (100) & +++ & + & - & - & ++ & - & - & - & - & + & ++ & ++ & - & - & - & +++ & - & - \\
\hline F0210-26Y3 (HG008759) & Pochonia suchlasporia (99) & - & - & - & - & ++ & - & - & - & - & - & - & - & - & - & - & - & - & - \\
\hline F0210-12L2 (HG008760) & Trichoderma sp. (98) & - & - & - & - & - & - & ++ & - & - & - & - & - & - & - & - & - & - & - \\
\hline F0910-25X1 (HG008761) & Trichophyton sp. (97) & - & - & - & - & - & - & - & - & - & - & - & - & - & +++ & - & - & - & - \\
\hline F0210-1A1 (HG008762) & Verticillium leptobactrum (99) & - & - & - & ++ & - & ++ & + & + & +++ & - & - & - & - & - & - & ++ & - & - \\
\hline \multicolumn{20}{|l|}{ Basidiomycota } \\
\hline F0910-30C2 (HG008763) & Bulleromyces albus (99) & - & - & - & - & - & - & - & - & - & - & - & - & +++ & - & +++ & - & - & - \\
\hline F0910-6F4 (HG008764) & Cryptococcus dimennae (98) & - & - & - & - & - & - & - & - & - & - & - & - & - & - & - & - & ++ & - \\
\hline F0210-53Y4 (HG008765) & Sporobolomyces sp. (99) & + & - & - & - & - & - & - & - & - & - & - & - & - & - & - & - & - & - \\
\hline F0910-49U1 (HG008766) & Sporobolomyces roseus (100) & - & - & - & - & - & - & - & - & - & - & + & - & - & - & - & - & - & - \\
\hline F0910-11K1 (HG008767) & $\begin{array}{l}\text { Sporobolomyces ruberrimus } \\
\text { (100) }\end{array}$ & - & - & - & - & - & - & - & - & - & - & - & - & - & - & - & + & - & - \\
\hline
\end{tabular}

concentrations represent a scarce percentage of the total air microbiota. Therefore, it is not surprising that O. lascauxensis was rarely detected with the method used in this study.

Taking into account the well-known limitations of culture-dependent approaches, future aerobiological studies should be complemented with molecular analyses of microbial communities using methods as construction of clone libraries or high-throughput sequencing. In this sense, an additional study performed in Lascaux Cave should be mentioned. Two clone libraries, based on the same rDNA regions, were also constructed to characterize the bacterial and fungal communities of one air sample collected the $21 \mathrm{st}$ September 2010 from the Passageway using a Coriolis sampler (data not shown). The molecular results showed a microbial diversity significantly higher than by culturing, especially for fungi. This difference could be due to the abundance of non-cultivable organisms and the high sensitivity of such molecular method.

\section{CONCLUSIONS}

The aerobiological analysis of samples yielded a representative inventory of the cultivable bacteria and fungi present in the Lascaux Cave, the estimation of their abundance and evolution along two different surveys in periods where a climate system was operating or remained inactive. Although visitors are not allowed at present in the cave, the aerobiological approach should be introduced as a routine monitoring in order to detect and prevent further outbreaks.

In all halls and galleries studied the quantifications of cultivable bacteria were higher than those of fungi. Bacteria and fungi were much higher in February (stratified air) than in September (convection currents). In the two samplings, the lowest amounts of bacteria and fungi were obtained in the Shaft of Dead Man which is the most inaccessible hall. The highest concentrations of bacteria were found in the Chamber of Felines (February) or in the Great Hall of Bulls (September) while the Painted Gallery showed the highest concentration of fungi both in February and September.

It is noteworthy that while two of the three microbial crises experienced in this cave were produced by fungi, their concentrations in air were similar to those found in other caves as well as the genera identified (Aspergillus, Cladosporium, Penicillium, Verticillium). However, bacterial concentrations were considerably higher, particularly Brachybacterium fresconis (February) and Microbacterium murale (September), both bacteria recently isolated and described from 
subterranean and indoor environments, respectively. The possible effect of these and other bacteria on the paintings is a topic not yet investigated.

Finally, the data showed that the management of the climate system had a noticeable influence on the concentration and dispersion of airborne microorganisms and open the question on the benefit of having an adaptive system based on the existing climate system in operation after each human presence in the cave in order to reduce the microbial charge in the air.

\section{ACKNOWLEDGMENTS}

This work was supported by the Ministry of Culture and Communication, France, project "Ecologie microbienne de la grotte de Lascaux" and the Spanish Ministry of Science and Innovation, "Research Programme in Technologies for the Assessment and Conservation of Cultural Heritage", TCP CSD2007-00058. EP was supported by a CSIC JAE-Predoc grant. The collaboration and facilities of Lascaux staff, restoration team and DRAC Aquitaine are acknowledged.

\section{REFERENCES}

Baskar S., Baskar R., Mauclaire L. \& McKenzie J.A., 2006 - Microbially induced calcite precipitation by culture experiments: Possible origin for stalactites in Sahastradhara caves, Dehradun, India. Current Science, 90: 58-64.

Baskar S., Baskar R., Lee N. \& Theophilus P.K., 2009 - Speleothems from Mawsmai and Krem Phyllut caves, Meghalaya, India: some evidences on biogenic activities. Environmental Geology, 57: 1169-1186. http://dx.doi.org/10.1007/s00254-008-1413-y

Bastian F., Alabouvette C. \& Saiz-Jimenez C., 2009 - The impact of arthropods on fungal community structure in Lascaux Cave. Journal of Applied Microbiology, 106: 1456-1462.

http://dx.doi.org/10.1111/j.1365-2672.2008.04121.x

Bastian F., Jurado V., Novakova A., Alabouvette C. \& Saiz-Jimenez C., 2010 - The microbiology of the Lascaux Cave. Microbiology, 156: 644-652. http://dx.doi.org/10.1099/mic.0.036160-0

De Leo F., Iero A., Zammit G. \& Urzi C., 2012 Chemoorganotrophic bacteria isolated from biodeteriorated surfaces in cave and catacombs. International Journal of Speleology, 41: 125-136. http://dx.doi.org/10.5038/1827-806X.41.2.1

Docampo S., Trigo M.M., Recio M., Melgar M., GarcíaSánchez J. \& Cabezudo B., 2011 - Fungal spore content of the atmosphere of the Cave of Nerja (southern Spain): diversity and origin. Science of the Total Environment, 409: 835-843.

http://dx.doi.org/10.1016/j.scitotenv.2010.10.048

Domínguez-Moñino I., Jurado V., Hermosin B. \& SaizJimenez C., 2012 - Aerobiología de cuevas andaluzas. In: Durán J.J. \& Robledo P.A. (Eds.), Las Cuevas Turísticas como Activos Económicos: Conservación e Innovación. Madrid: ACTE: 299-308.

Dupont J., Jacquet C., Dennetiere B., Lacoste S., Bousta F., Orial G., Cruaud C., Couloux A. \& Roquebert M-F., 2007 - Invasion of the French Paleolithic painted cave of Lascaux by members of the Fusarium solani species complex. Mycologia, 99: 526-533.

http://dx.doi.org/10.3852/mycologia.99.4.526
Godoy G., Rodríguez-Kábana R. \& Morgan-Jones G., 1982 - Parasitism of eggs of Heterodera glycines and Meloidogyne arenaria by fungi isolated from cysts of $H$. glycines. Nematropica, 12: 111-119.

Golubev W., Ikeda R., Shinoda T. \& Nakase T., 1997 - Antifungal activity of Bullera alba (Hanna) Derx. Mycoscience, 38: 25-29.

http://dx.doi.org/10.1007/BF02464965

Heyrman J., Balcaen A., De Vos P., Schumann P. \& Swings J., 2002 - Brachybacterium fresconis sp. nov. and Brachybacterium sacelli $s p$. nov., isolated from deteriorated parts of a medieval wall painting of the chapel of Castle Herberstein (Austria). International Journal of Systematic and Evolutionary Microbiology, 52: 1641-1646.

http://dx.doi.org/10.1099/ijs.0.02229-0

Kämpfer P., Schäfer J., Lodders N. \& Martin K., 2012 - Microbacterium murale sp. nov., isolated from an indoor wall. International Journal of Systematic and Evolutionary Microbiology, 62: 2669-2673. http://dx.doi.org/10.1099/ijs.0.037705-0

Koilraj A.J., Marimuthu G., Natarajan K., Saravanan S., Maran P. \& Hsu M.J. 1999 - Fungal diversity inside caves of southern India. Current Science, 77: 1081-1084.

Lacanette D., Vincent S., Sarthou A., Malaurent P. \& Caltagirone J.P., 2009 - An Eulerian/Lagrangian method for the numerical simulation of incompressible flows interacting with complex obstacles: application to the natural convection in the cave of Lascaux. International Journal of Heat and Mass Transfer, 52: 2528-2542.

http://dx.doi.org/10.1016/j.ijheatmasstransfer.2008.12.028

Laiz L., Groth I., Gonzalez J.M. \& Saiz-Jimenez C., 1999 - Microbiological study of the dripping waters in Altamira cave (Santillana del Mar, Spain). Journal of Microbiological Methods, 36: 129-138. http://dx.doi.org/10.1016/S0167-7012(99)00018-4

Laiz L., Groth I., Schumann P., Zezza F., Felske A., Hermosin B. \& Saiz-Jimenez C., 2000a - Microbiology of the stalactites from Grotta dei Cervi, Porto Badisco, Italy. International Microbiology, 3: 25-30.

Laiz L., Hermosin B., Caballero B. \& Saiz-Jimenez C., $2000 \mathrm{~b}$ - Bacteria isolated from the rocks supporting prehistoric paintings in two shelters from Sierra de Cazorla, Jaen, Spain. Aerobiologia, 16: 119-124. http://dx.doi.org/10.1023/A:1007684904350

Lalucat J., Bennasar A., Bosch R., García-Valdés E. \& Palleroni N.J., 2006 - Biology of Pseudomonas stutzeri. Microbiology and Molecular Biology Reviews, 70: 510547. http://dx.doi.org/10.1128/MMBR.00047-05

Lane D.J., 1991 - 16S/23S rRNA sequencing. In: Stackenbrandt E. \& Goodfellow M. (Eds.), Nucleic acid techniques in bacterial systematic. Chichester: John Wiley: 115-175.

Lefèvre M., 1974 - La maladie verte de Lascaux. Studies in Conservation, 19: 126-156. http://dx.doi.org/10.2307/1505660

Lefèvre M. \& Laporte G.S., 1969 - The 'maladie verte' of Lascaux. Diagnosis and treatment. Studies in Speleology, 2: 35-44.

Malaurent P., Lacanette D., Brunet J. \& Riss J., 2011 Climatology of the subterranean environment at Lascaux: from a global study to the microclimatology of the cave walls. In: Coye N. (Ed.), Lascaux and preservation issues in subterranean environments. Proceedings of the International Symposium. Documents d'archéologie française 105. Paris: Éditions de la Maison des sciences de l'homme: 121-142. 
Martin-Sanchez P.M., Novákóva A., Bastian F., Alabouvette C. \& Saiz-Jimenez C., 2012a - Two new species of the genus Ochroconis, O. lascauxensis and $O$. anomala isolated from black stains in Lascaux Cave, France. Fungal Biology, 116: 574-589.

http://dx.doi.org/10.1016/j.funbio.2012.02.006

Martin-SanchezP.M., NovákóvaA., Bastian F., Alabouvette C. \& Saiz-Jimenez C., 2012b - The use of biocides for the control of fungal outbreaks in subterranean environments: The case of the Lascaux Cave in France. Environmental Science and Technology, 46: 37623770. http://dx.doi.org/10.1021/es2040625

Martin-Sanchez P.M., Bastian F., Alabouvette C. \& Saiz-Jimenez C., 2013 - Real-Time PCR detection of Ochroconis lascauxensis involved in the formation of black stains in the Lascaux Cave, France. Science of the Total Environment, 443: 478-484.

http://dx.doi.org/10.1016/j.scitotenv.2012.11.026

Monte, M. \& Ferrari, R., 2000 - Airborne microorganisms in a subterranean archaeological area of the basilica of San Lorenzo in Lucina (Rome). Aerobiologia, 16: 435439. http://dx.doi.org/10.1023/A:1026510423751

Mulet M., David Z., Nogales B., Bosch R., Lalucat J. \& García-Valdés E., 2011 - Pseudomonas diversity in crude-oil-contaminated intertidal sand samples obtained after the Prestige oil spill. Applied and Environmental Microbiology, 77: 1076-1085.

http://dx.doi.org/10.1128/AEM.01741-10

Nagai K., Suzuki K. \& Okada, G., 1998 - Studies on the distribution of alkalophilic and alkali-tolerant soil fungi II: Fungal flora in two limestone caves in Japan. Mycoscience, 39: 293-298. http://dx.doi.org/10.1007/BF02464011

Nováková A., 2009 - Microscopic fungi isolated from the Domica Cave system (Slovak Karst National Park, Slovakia). A review. International Journal of Speleology, 38: 71-82. http://dx.doi.org/10.5038/1827-806X.38.1.8

Nugari M.P. \& Roccardi A., 2001 - Aerobiological investigations applied to the conservation of cultural heritage. Aerobiologia, 17: 215-223.

http://dx.doi.org/10.1023/A:1011841410357
Orial G., Bousta F., François A., Pallot-Frossard I. \& Warscheid T., 2011 - Managing biological activities in Lascaux: Identification of microorganisms, monitoring and treatments. In: Coye N. (Ed.), Lascaux and preservation issues in subterranean environments. Proceedings of the International Symposium. Documents d'archéologie française 105. Paris: Éditions de la Maison des sciences de l'homme: 219-251.

Porca E., Jurado V., Martin-Sanchez P.M., Hermosin B., Bastian F., Alabouvette C. \& Saiz-Jimenez C., 2011 Aerobiology: An ecological indicator for early detection and control of fungal outbreaks in caves. Ecological Indicators, 11: 1594-1598. http://dx.doi.org/10.1016/j.ecolind.2011.04.003

Saiz-Jimenez C., Miller A.Z., Martin-Sanchez P.M. \& Hernandez-Marine M., 2012 - Uncovering the origin of the black stains in Lascaux Cave in France. Environmental Microbiology, 14: 3220-3231. http://dx.doi.org/10.1111/1462-2920.12008

Snaidr J., Amann R., Huber I., Ludwig W. \& Schleifer K.-H., 1997 - Phylogenetic analysis and in situ identification of bacteria in activated sludge. Applied and Environmental Microbiology, 63: 2884-2896.

Vaughan M.J., Maier R.M. \& Pryor B.M., 2011- Fungal communities on speleothem surfaces in Kartchner Caverns, Arizona, USA. International Journal of Speleology, 40: 65-77. http://dx.doi.org/10.5038/1827-806X.40.1.8

Wang W., Ma X., Ma Y., Mao L., Wu F., Ma X., An L. \& Feng H., 2010 - Seasonal dynamics of airborne fungi in different caves of the Mogao Grottoes, Dunhuang, China. International Biodeterioration and Biodegradation, 64: 461-466. http://dx.doi.org/10.1016/j.ibiod.2010.05.005

White T.J., Bruns T., Lee S. \& Taylor J., 1990 -Amplification and direct sequencing of fungal ribosomal RNA genes for phylogenetics. In: Innis M.A., Gelfand D.H., Sninsky J.J. \& White T.J. (Eds.), PCR protocols: a guide to methods and applications. London: Academic Press: 315-322. 